ОБҐРУНТУВАННЯ ДОДАТКОВИХ ФУНКЦІЙ ПЕРСОНАЛУ ЯК ВДОСКОНАЛЕННЯ ОРГАНІЗАЦІЙНОГО ЗАБЕЗПЕЧЕННЯ УПРАВЛІННЯ РОЗВИТКОМ ПРОМИСЛОВОГО ПІДПРИЄМСТВА

\title{
SUBSTANTIATION OF ADDITIONAL FUNCTIONS OF PERSONNEL AS IMPROVEMENT OF ORGANIZATIONAL SUPPORT OF INDUSTRIAL ENTERPRISE DEVELOPMENT MANAGEMENT
}

Удк 658.1:334.716

https://doi.org/10.32843/infrastruct43-31

Квілінський О.с. ${ }^{1}$

габілітований доктор економічних наук Інститут розвитку міжнародної співпраці, м. Познань, Польща

Kwiliński Aleksy

Institute for International Cooperation Development

\begin{abstract}
У статmі запропоновано підхід до організачійного забезпечення управління розвитком промислового підприємства в умовах інфрормаційної економіки на основі розроблення додаткових функцій персоналу, виконання яких забезпечить реалізацію механізмів оцінювання конкурентоспроможності підпри ємства в інфрормаційній економіці та модернізації виробничої сфрери згідно з вимогами ринкового інсрормаційного середовища, таких як автоматизація виробництва та забезпечення гармонічності між вхідними та вихідними інформаційними потужностями бізнес-процесів промислового підприємства. Для забезпечення реалізації механізмів оцінювання конкурентоспроможності підприємства в інфрормаційній економіці та модернізації виробничої сорери заідно з вимогами ринкового інформаційного середовища запропоновано підхід до розроблення організаційного забезпечення управління розвитком промислового підприємства в умовах інсрормаційної економіки на основі діючої організаційної структури управління підприємством внаслідок розроблення додаткових функцій персоналу.

Ключові слова: додаткові фрункції, персонал, організаційне забезпечення, управління, розвиток, промислове підприємство.
\end{abstract}

В статье предложен подход к организационному обеспечению управления развитием промышленного предприятия в условиях инорормационной экономики на основе разработки дополнительных функций персонала, выполнение которых обеспечит реализацию механизмов оценивания конкурентоспособности предприятия в информационной экономике и модернизации производственной сфреры в соответствии с требованиями рыночной информационной среды, таких как автоматизация производства $и$ обеспечение гармоничности между входящими и исходящими инорормационными мощностями бизнес-процессов промышленного предприятия. Для обеспечения реализации механизмов оценивания конкурентоспособности предприятия $в$ инорормационной экономике и модернизации производственной сореры в соответствии с требованиями рыночной информационной среды предложен подход к разработке организационного обеспечения управления развитием промышленного предприятия в условиях информационной экономики на основе действующей организационной структуры управления предприятием вследствие разработки дополнительных функций персонала.

Ключевые слова: дополнительные функции, персонал, организационное обеспечение, управление, развитие, промышленное предприятие.

The paper proposes an approach to organizational management of the development of the industrial enterprise under information economy conditions based on of the development of additional functions of the personnel, which will ensure the implementation of mechanisms for assessing the competitiveness of the enterprise in the information economy and modernization of the manufacturing sector in accordance with the requirements of the market information environment: automation of production and ensuring the harmony between input and output information capabilities of business processes of the industrial enterprise. Organizational support for the management of industrial enterprise development in an information economy should include a set of appropriate tools and methods for organizing interaction between individual performers and managers based on of appropriate regulations. To ensure the implementation of mechanisms for assessing the competitiveness of an enterprise in the information economy and the modernization of the production sphere in accordance with the requirements of a market information environment, i.e. automation of production and security harmony between the input and output pressures of the business processes of industrial enterprises, an approach to the development of organizational support for the development of an industrial enterprise in the information economy based on the existing organizational structure of enterprise management as a result of the development of additional personnel functions is proposed. It is proved that as a result of the implementation of the concept of management of the development of an industrial enterprise under information economy conditions there will be additional new functions in the personnel of the design and development department, production service, quality service, planning and economic department and IT department. Additional functions are distributed among existing staff, the introduction of new positions as a result of the implementation of the concept of management of the development of industrial enterprises under information economy conditions is not mandatory, which, makes the proposed organizational provision low cost at the expense and time.

Key words: additional functions, personnel, organizational support, management, development, industrial enterprise.

Постановка проблеми. Управління розвитком промислового підприємства в умовах інорормаційної економіки вимагає не тільки виробничих, економічних, кадрових змін, але й організаційних, спрямованих на максимальне досягнення відповідності промислового підприємства вимогам інформаційної економіки задля забезпечення

\footnotetext{
${ }^{1}$ aleksy.kwilinski@institute-icd.org

ORCID: https://orcid.org/0000-0001-6318-4001

Researcher ID: B-7526-2017

Scopus Author ID: 57204068618
}

найбільш повного використання виробничого потенціалу підприємства на основі використання ринкових переваг інсрормаційної економіки.

Аналіз останніх досліджень і публікацій. Питання розроблення організаційного забезпечення управління на промислових підприємствах розглядалися в роботах таких науковців, як М.Г. Чумаченко, О.П. Савченко, В.Г. Коренев [1], В.М. Гриньова [2], І.С. Грозний [3; 12], В.В. Рябенко [4] О.В. Харчишина [5], О.М. Ястремська [6], О.С. Квілінський [7-11], Н.М. Далевська, С.І. Кравченко [12], В.М. Лахно [13], В.В. Ткаченко [14], проте з точки зору роботи 
підприємства в умовах інформаційної економіки залишились недостатньо відкритими.

Постановка завдання. Метою статті є обґрунтування додаткових фрункцій персоналу як удосконалення організаційного забезпечення управління розвитком промислового підприємства.

Виклад основного матеріалу дослідження. Під організаційним забезпеченням управління розвитком промислового підприємства в умовах інорормаційної економіки необхідно розуміти узгодженість методів та засобів вжиття визначених заходів з формування стратегії розвитку підприємства з урахуванням вимог інфрормаційної економіки в процесі сумісного функціонування керівників та виконавців у сорері розподілу зони їх обов'язків та відповідальності. В основу організаційного забезпечення управління розвитком промислового підприємства в умовах інорормаційної економіки має бути покладено нормативно-правове регулювання діяльності підприємства з урахуванням специфіки його фрункціонування в зовнішньому середовищі.

Організаційне забезпечення управління розвитком промислового підприємства в умовах інформаційної економіки має включати сукупність відповідних засобів та методів організації взаємодії між окремими виконавцями та керівниками на основі відповідного нормативного забезпечення. До організаційного забезпечення управління розвитком промислового підприємства в умовах інорормаційної економіки необхідно додати схему організаційної структури управління підприємства, перелік працівників, посадові інструкції, уніфріковані нормативні документи та інші внутрішні розпорядчі документи.

Для промислового підприємства, а саме машинобудівного, інфрормаційну економіку пропонуємо розглядати в розрізі автоматизації управління за такими основними напрямами:

- дослідження та оптимізація систем управління промисловими підприємствами;

- розроблення й реалізація економіко-математичних та інформаційних моделей систем управління промисловими підприємствами;

- формалізація бізнес-процесів підприємства до рівня функціональних моделей і моделей потоків даних;

- впровадження баз знань і баз даних інфрормаційних систем підприємств;

- впровадження, експлуатація та супровід інформаційних систем управління підприємствами класу MRP II і ERP;

- впровадження спеціалізованих IT-рішень, максимально орієнтованих на специфрічні бізнеспроцеси різних галузей (виробництво, видобуток, зв'язок, освіта, бюджетна сфрера, державне управління).

Таким чином, оптимальною для машинобудівного підприємства $€$ інтегрована система управління, заснована на використанні єдиної інфрормаційної бази, побудованої на єдиній ідеології, яка охоплює організаційні, програмні, технологічні, методичні та інші аспекти системи управління за такими напрямами, як технічна підготовка виробництва; керування виробництвом; управління матеріально-технічним забезпеченням; управління витратами; збут і маркетинг; бухгалтерський і податковий облік; управління персоналом; планування та облік заробітної плати; аналіз господарської діяльності.

Система повинна інтегрувати всю управлінську інфрормацію, видавати їі у вигляді, зручному для аналізу та ухвалення рішень. Маючи всю необхідну інформацію про реальний поточний стан підприємства, яка структурована таким чином, що виявляються всі «вузькі місця», керівник контролює всю виробничо-господарську діяльність. Це $€$ головним фрактором, основною умовою того, що підприємство отримає віддачу від інвестицій, спрямованих на розвиток інформаційних технологій на підприємстві.

Важливою умовою впровадження системи автоматизованого управління $€$ те, що її впровадження має проходити спільно з працівниками підприємства. Крім того, проводиться аналіз потреб підприємства, досліджуються специфріка та принципові особливості його виробничо-господарської діяльності, здійснюються розроблення, налаштування й конфрігурація системи відповідно до специфріки підприємства. За необхідності відбуваються доопрацювання системи, навчання й перекваліфрікація персоналу відповідно до цієї специфріки.

За такого підходу процес впровадження доводиться до кінцевого результату з точки зору підприємства, оскільки під час індивідуального розроблення та налагодження системи враховуються всі особливості до найменших нюансів. Причому під час впровадження відбувається не тільки налаштування системи, але й консалтинг, що дає змогу використовувати весь попередній досвід і сучасні концепції автоматизації управління підприємством. При цьому адаптація системи під конкретне підприємство відбувається 3 максимальною орієнтацією на сорормовані структури й методи управління.

На основі проведеного аналізу організаційної структури управління підприємства та ключових посадових обов'язків персоналу під час фрормування та виконання замовлення на виробництво продукції можна зробити висновок, що реалізація концепції управління розвитком підприємства в умовах інфрормаційної економіки вимагає здійснення суттєвих змін в реорганізації наявної структури управління, а саме необхідний комплекс нових функцій наявних служб та відділів підприємства (табл. 1). 
Перелік додаткових функцій персоналу в результаті впровадження концепції управліния 1 розвитком підприємства в умовах інформаційної економіки

\begin{tabular}{|c|c|c|}
\hline Відділ & Посада & Нові функції (додаткові) \\
\hline 1 & 2 & 3 \\
\hline $\begin{array}{l}\text { Проєктно-конструкторський } \\
\text { відділ (ПКО) }\end{array}$ & $\begin{array}{l}\text { Заступник голови } \\
\text { правління } 3 \\
\text { наукової роботи }\end{array}$ & $\begin{array}{l}\text { Встановлення відповідності промислового підприємства } \\
\text { умовам інсрормаційної економіки; } \\
\text { оцінювання конкурентоспроможності підприємства; } \\
\text { проведення системного аналізу для визначення інтегрального } \\
\text { показника конкурентоспроможності; } \\
\text { оцінювання конкурентоспроможності інорормаційних потоків, } \\
\text { якості оброблення інфрормації на промисловому підприємстві; } \\
\text { побудова інформаційних систем моніторингу зовнішнього } \\
\text { середовища; } \\
\text { аналіз конкурентоспроможності промислового підприємства в } \\
\text { макрооточенні. }\end{array}$ \\
\hline Виробнича служба & $\begin{array}{l}\text { Заступник } \\
\text { голови правління } \\
\text { з підготовки } \\
\text { виробництва та } \\
\text { логістики }\end{array}$ & $\begin{array}{l}\text { Проведення системного аналізу для розподілу заходів з } \\
\text { модернізації між підрозділами підприємства; } \\
\text { встановлення залежностей між виробничими підрозділами під } \\
\text { час вжиття заходів розвитку відповідно до вимог інорормаційної } \\
\text { економіки; } \\
\text { виконання первинного набору можливих заходів з модернізації } \\
\text { виробництва; } \\
\text { встановлення послідовності заходів розвитку та їх } \\
\text { пріоритетності; } \\
\text { проведення розрахунку потреб у ресурсах; } \\
\text { групування окремих заходів розвитку відповідно до умов } \\
\text { інфрормаційної економіки в окремі проєкти; } \\
\text { проведення розрахунку наслідків заходів з модернізації } \\
\text { виробництва для підприємства; } \\
\text { проведення розрахунку наслідків заходів з модернізації } \\
\text { виробництва підприємства для контрагентів, споживачів та } \\
\text { конкурентів; } \\
\text { проведення оцінювання заходів з модернізації виробництва } \\
\text { промислового підприємства у ссрері автоматизації та } \\
\text { інорорматизації; } \\
\text { проведення системного аналізу узодження спеціалізованих } \\
\text { бізнес-процесів з управлінськими бізнес-процесами; } \\
\text { інтеграція систем управління спеціалізованими бізнес- } \\
\text { процесами до загальної системи управління промисловим } \\
\text { підприємством. }\end{array}$ \\
\hline Служба якості & $\begin{array}{l}\text { Начальник відділу } \\
\text { якості, метрології та } \\
\text { сертифікації }\end{array}$ & $\begin{array}{l}\text { Оцінювання впливів заходів на якість управлінських рішень та } \\
\text { оптимізації проєктів розвитку управлінської сфери; } \\
\text { розроблення інструментів збереження, якості контролю та } \\
\text { попередньої обробки управлінської інформації; } \\
\text { оцінювання якості управління щодо конкурентоспроможності } \\
\text { промислового підприємства. }\end{array}$ \\
\hline $\begin{array}{l}\text { Бухгалтерія (планово- } \\
\text { економічний відділ) }\end{array}$ & Старший економіст & $\begin{array}{l}\text { Проведення порівняльного оцінювання } \\
\text { конкурентоспроможності промислового підприємства; } \\
\text { проведення оцінювання спроможності промислового } \\
\text { підприємства до впровадження нових технологій; } \\
\text { надання інтегрованої кількісної оцінки конкурентоспроможності; } \\
\text { надання кількісної оцінки інфрорматизації та автоматизації } \\
\text { бізнес-процесів; } \\
\text { визначення конкурентної позиції промислового підприємства в } \\
\text { ринковому середовищі; } \\
\text { проведення оцінювання наявності у підприємства } \\
\text { висококваліфікованого персоналу; } \\
\text { проведення оцінювання кваліфікації персоналу у сфері } \\
\text { інорормаційних технологій; } \\
\text { оцінювання наявності ресурсів (фрінансових) для проведення } \\
\text { модернізації та впровадження новітніх технологій. }\end{array}$ \\
\hline Виробнича служба & $\begin{array}{l}\text { Начальник } \\
\text { виробництва }\end{array}$ & $\begin{array}{l}\text { Проведення оцінювання ефекту від вжиття заходів з } \\
\text { модернізації виробничої сфери; } \\
\text { проведення оцінювання узгодження проєктів модернізації } \\
\text { виробничої сфери до умов інформаційної економіки; } \\
\text { проведення оцінювання наслідків модернізації для } \\
\text { конкурентоспроможності підприємства та фрінансового } \\
\text { результату. }\end{array}$ \\
\hline
\end{tabular}


Закінчення табл. 1

\begin{tabular}{|c|c|c|}
\hline 1 & 2 & 3 \\
\hline Відділ IT & $\begin{array}{l}\text { Системний } \\
\text { адміністратор }\end{array}$ & $\begin{array}{l}\text { Проведення оцінювання урівноваження інорормаційних } \\
\text { потужностей пов'язаних бізнес-процесів; } \\
\text { проведення оцінювання забезпечення гармонічності між } \\
\text { вхідними та вихідними інформаційними потужностями бізнес- } \\
\text { процесів промислового підприємства; } \\
\text { проведення оцінювання узгодження каналів передачі } \\
\text { інформації між спеціалізованими підрозділами промислового } \\
\text { підприємства та керівництвом; } \\
\text { формування заходів з усунення виявлених відхилень за } \\
\text { результатами оцінювання; } \\
\text { аналіз комерційних пропозицій з постачання програмного } \\
\text { забезпечення автоматизації виробничих процесів; } \\
\text { вибір постачальника програмного забезпечення для } \\
\text { проведення автоматизації виробництва; } \\
\text { проведення тестових випробувань програмного забезпечення } \\
\text { автоматизації виробництва; } \\
\text { складання та подання на розгляд технічного завдання з } \\
\text { проведення автоматизації виробництва. }\end{array}$ \\
\hline
\end{tabular}

Таким чином, можна зробити висновок, що в результаті реалізації концепції управління розвитком промислового підприємства в умовах інформаційної економіки виникнуть додаткові нові фрункції персоналу проєктно-конструкторського відділу, виробничої служби, служби якості, планово-економічного відділу та відділу ІT. 3 урахуванням того, що додаткові фрунції розподіллено між наявним персоналом, впровадження нових посад внаслідок реалізації концепції управління розвитком промислового підприємства в умовах інформаційної економіки не є обов'язковим, що робить запропоноване організаційне забезпечення маловитратним за коштами та часом.

Висновки 3 проведеного дослідження. Для забезпечення реалізації механізмів оцінювання конкурентоспроможності підприємства в інфрормаційній економіці та модернізації виробничої сорери згідно з вимогами ринкового інформаційного середовища слід вжити таких заходів, як автоматизації виробництва та забезпечення гармонійності між вхідними та вихідними інформаційними потужностями бізнес-процесів промислового підприємства, запровадження підходу до розроблення організаційного забезпечення управління розвитком промислового підприємства в умовах інформаційної економіки на основі діючої організаційної структури управління підприємством внаслідок розроблення додаткових фрункцій персоналу.

\section{БІБЛІОГРАФІЧНИЙ СПИСОК:}

1. Чумаченко Н.Г., Савченко А.П., Коренев В.Г. Проектирование организационных структур управления производством : монография. Киев : Наукова думка, 1979. 258 с.

2. Гриньова В.М., Попов О.Є. Організаційно-економічні основи формування системи корпоративного управління в Україні : монографрія. Харків : ХДЕУ, 2003. 324 c.

3. Грозний І.С. Необхідність проведення реінжинірингу виробничих процесів в управлінні якістю розвитку промислових підприємств. Ефективна економіка. 2015. № 10. С. 31-34.

4. Рябенко В.В. Організація механізму управління формуванням стратегічного потенціалу підприємств харчової промисловості. Стратегія економічного розвитку України. 2014. № 34. С. 82-86.

5. Харчишина О.В. Формування організаційної культури в системі менеджменту підприємств харчової промисловості : монографрія. Житомир : вид-во ЖДУ ім. І. Франка, 2011. 290 с.

6. Ястремська О.М., Яковенко К.В., Томах В.В. Організаційне забезпечення якості трудової діяльності керівників промислових підприємств : монографрія. Харків : ХНЕУ, 2009. 328 с.

7. Kwilinski A. Mechanism of modernization of industrial sphere of industrial enterprise in accordance with requirements of the information economy. Marketing and Management of Innovations. 2018. № 4. S. 116-128. DOI: http://doi.org/10.21272/mmi.2018.4-11.

8. Kwilinski A. Development of industrial enterprise in the conditions of formation of information economics. Thai Science Review. 2017. P. 85-90. DOI: https:// doi.org/10.5281/zenodo.1414236.

9. Kwilinski A. Mechanism of formation of industrial enterprise development strategy in the information economy. Virtual Economics. 2018. № 1 (1). P. 7-25. DOI: https://doi.org/10.34021/ve.2018.01.01(1).

10. Kwilinski A. Mechanism for assessing the competitiveness of an industrial enterprise in the information economy. Research Papers in Economics and Finance. 2018. № 3 (1). P. 7-16. DOI https:// doi.org/10.18559/ref.2018.1.1.

11. Kwilinski A. Trends of development of the information economy of Ukraine in the context of ensuring the communicative component of industrial enterprises. Economics and Management. 2018. № 1 (77). P. 64-70.

12. Formation of the entrepreneurship model of e-business in the context of the introduction of information 
and communication technologies / A. Kwilinski, N. Dalevska, S. Kravchenko, I. Hroznyi, I. Kovalenko. Journal of Entrepreneurship Education. 2019. № 22. Special Issue 1 : Entrepreneurship: Investment and Innovation. P. 1528-2651-22-S1-337: 1-7.

13. Model of managing of the procedure of mutual financial investing in information technologies and smart city systems / V. Lakhno, V. Malyukov, T. Bochulia, Z. Hipters, A. Kwilinski, O. Tomashevska. International Journal of Civil Engineering and Technology. 2018. № 9 (8). P. 1802-1812. URL: http://www.iaeme.com/ MasterAdmin/UploadFolder/IJCIET_09_08_181/ IJCIET_09_08_181.pdf.

14. Assessment of information technologies influence on financial security of economy / V. Tkachenko, A. Kwilinski, O. Korystin, N. Svyrydiuk, I. Tkachenko. Journal of Security and Sustainability. 2019. № 8 (3). P. 375-385. DOI: https://doi.org/10.9770/ jssi.2019.8.3(7).

\section{REFERENCES:}

1. Chumachenko, N.G., Savchenko, A.P., Korenev, V.G. (1979). Design of organizational structures of production management: monograph. K.: Naukova dumka. (in Ukrainian)

2. Grinyova, V.M., Popov, O.E. (2003). Organizational and economic bases of formation of the corporate governance system in Ukraine. H.: KhDEU. (in Ukrainian)

3. Hroznyi, I.S. (2015). The need for reengineering of production processes in the quality management of industrial enterprises. Electronic scientific publication Effective Economy, Dnepropetrovsk: State Agrarian University, № 10, 31-34.

4. Ryabenko, V.V. (2014). Organization of the mechanism of management of formation of strategic potential of enterprises of food industry. Strategy of economic development of Ukraine, № 34, 82-86.

5. Harchishina, OV (2011). Formation of organizational culture in the system of management of food industry enterprises: monograph. Zhytomyr: ZhSU Publishing House. I. Franko. (in Ukrainian)

6. Yastremskaya, O.M., Yakovenko, K.V., Tomakh, V.V. (2009). Organizational support of quality of labor activity of heads of industrial enterprises: monograph. $\mathrm{H}$.: HNEU. (in Ukrainian)

7. Kwilinski, A. (2018). Mechanism of modernization of industrial sphere of industrial enterprise in accordance with requirements of the information economy. Marketing and Management of Innovations, № 4, 116-128. Access mode: http://doi.org/10.21272/mmi.2018.4-11.

8. Kwilinski, A. (2017). Development of industrial enterprise in the conditions of formation of information economics. Thai Science Review, autumn 2017, 85-90. Access mode: https://doi.org/10.5281/zenodo.1414236.

9. Kwilinski, A. (2018). Mechanism of formation of industrial enterprise development strategy in the information economy. Virtual Economics, 1 (1). 7-25. Access mode: https://doi.org/10.34021/ve.2018.01.01(1).

10. Kwilinski, A. (2018). Mechanism for assessing the competitiveness of an industrial enterprise in the information economy. Research Papers in Economics and Finance, № 3 (1), 7-16. Access mode: https://doi.org/10.18559/ref.2018.1.1.

11. Kwilinski, A. (2018). Trends of development of the information economy of Ukraine in the context of ensuring the communicative component of industrial enterprises. Economics and Management, № 1 (77), 64-70.

12. Kwilinski, A., Dalevska, N., Kravchenko, S., Hroznyi, I., Kovalenko I. (2019). Formation of the entrepreneurship model of e-business in the context of the introduction of information and communication technologies. Journal of Entrepreneurship Education, № 22, Special Issue 1: Entrepreneurship: Investment and Innovation, 1528-2651-22-S1-337: 1-7.

13. Lakhno, V., Malyukov, V., Bochulia, T., Hipters, Z., Kwilinski, A., Tomashevska O. (2018). Model of managing the procedure of mutual financial investing in information technologies and smart city systems. International Journal of Civil Engineering and Technology, № 9 (8), 1802-1812. Access mode: http://www.iaeme. com/MasterAdmin/UploadFolder/IJCIET_09_08_181/ IJCIET_09_08_181.pdf.

14. Tkachenko, V., Kwilinski, A., Korystin, O., Svyrydiuk, N., Tkachenko I. (2019). Assessment of information technologies influence on financial security of economy. Journal of Security and Sustainability, № 8 (3), 375-385. Access mode: https://doi.org/10.9770/ jssi.2019.8.3(7). 